\title{
Oxidative Stability and Physico-chemical Properties of Meat from Broilers Fed with Dietary Neem Leaf Powder, Spirulina and their Combination
}

\author{
Ravi KILLI ${ }^{1 *}$, Bharavi KAITHEPALLI ${ }^{2}$, Ravi Kumar PENTELA ${ }^{1}$, Eswar Rao BANDI ${ }^{3}$, Vamsi \\ Krishna BOBBA ${ }^{1}$, Satish Kumar S.V. CHITTURI ${ }^{4}$ \\ ${ }^{I}$ NTR College of Veterinary Science, Department of Veterinary Pharmacology and Toxicology, Gannavaram, Krishna Dt., 521102 Andhra Pradesh, India; \\ ravi.k.bunty@gmail.com(*correspondingauthor);ravikumarp58@yahoo.com;vamsikrishnabobba@gmail.com \\ ${ }^{2}$ College of Veterinary Science, Department of Veterinary Pharmacology and Toxicology, Proddatur, Andhrapradesh, India; bharavi@yahoo.com \\ ${ }^{3}$ College of Veterinary Science, Deparment of Livestock Products Technology, Proddatur, Andhrapradesh, India; beraolpt@gmail.com \\ ${ }^{4}$ College of Veterinary Science Rajendranagar, Department of Veterinary Parmacology and Toxicology, Telangana, India; satish513512@gmail.com
}

\begin{abstract}
This 6 week study was conducted to evaluate the antioxidant potential, maintaining quality and sensory properties of broiler meat from birds fed on dietary neem leaf powder (NLP). A total of 90 Vencobb broiler chicks were randomly allotted to 6 groups of 15 birds in each. Dietary treatments consisted of normal diet (control Group I), feed containing terramycin-200 (TM-200*) at the concentration of $0.05 \%$ (Group II), feed containing NLP of $0.2 \%$ (Group III), feed containing NLP of $0.2 \%$ and spirulina of $1 \%$ (Group IV), feed containing TM-200 at $0.05 \%$ and spirulina of $1 \%$ (Group V) and feed containing spirulina of $1 \%$ (Group VI). At the end of the experiment liver, kidney and muscle samples were collected to evaluate the tissue peroxidation (TBARS and protein carbonyls) and antioxidant markers (SOD). Physico-chemical quality determinants of both fresh and preserved meat viz. extract release volume (ERV), water holding capacity (WHC) and $\mathrm{pH}$ were also studied. TBARS protein carbonyls indicated a significant $(\mathrm{P}<$ 0.05 ) decrease in all the treated groups when compared to control. Superoxide dismutase levels were found to be significantly increased in all the treated groups, in all the tissues collected. Compared to control group, favorable physico-chemical quality determinants were recorded in all the treated groups. The sensory attributes did not show significant $(\mathrm{P}<0.05)$ differences for color, flavor, juiciness, tenderness and overall acceptability. This study indicates enhanced stress tolerance levels, improved meat quality with unaffected consumer acceptance levels of the meat observed in the study, from broilers fed with neem and spirulina either alone or in combinationsș this points out that neem at $0.2 \%$ level can be used in poultry diets instead of antibiotic growth promoters (AGP).
\end{abstract}

Abbreviations: AGP-Antibiotic growth promoters; NLP-Neem leaf powder;TBARS-Thiobarbituric acid reactive substances; SOD-Superoxide dismutase; ERV-Extract release volume;WHC-Water holding capacity; NADPH-Nicotinamide adenine dinucleotide phosphate

Keywords: neem leaf powder, oxytetracycline, physico-chemical quality, spirulina

\section{Introduction}

Antibiotic growth promoters (AGP) at sub-therapeutic level improve overall performance of poultry (Falcão-eCunha et al., 2007). In recent years the usage of many antimicrobial drugs was banned due to their possible harmful effects on consumers (Black, 1984; Donoghue, 2003). The ban on the use of antibiotic feed additives has triggered intensive research to find and develop alternative strategies to maintain health and performance in poultry production. There is also an increasing public and governmental pressure in several countries to search for natural alternatives to antibiotics (McCartney, 2002). As a consequence, plant products are emerging as potential replacements for AGP (Charis, 2000). Plant derived products have proven to be neutral, less toxic, residue free and are thought to be ideal feed additives in food animal production (Hashemi et al., 2008). Generally, plant products do not develop or aid in the development of drug resistance (Tipu et al., 2006). Further, broilers fed on herbal feed additives are well accepted by the consumers (Hernandez et al., 2004).

Oxidatation is a very general process that affects lipids, proteins and carbohydrates (Kanner, 1994). Environmental stress diminishes in vivo antioxidant status and results in oxidative damage (Klasing, 1998; Sahin et al., 2001). Muscle tissue oxidation continues after slaughter and determines the shelf-life of the meat. Lipid oxidation and oxidative rancidity are often decisive factors in determining the useful storage life of food products. To maximize the oxidative stability of meat, antioxidants, mostly synthetic, are added to animal feed. 
Azadirachata indica A. Juss, commonly known as neem, is extensively used in Ayurveda, Unani as homoeopathic medicine and has become a cynosure for modern medicine (Koul and Opender, 1990; Subapriya and Nagini, 2005). Neem leaves contain a vast array of chemically diverse and active ingredients (Devakumar and Skutt, 1993). A wide range of medicinal utilities and wide range of pharmacological activities have been described for neem leaf (Durrani et al., 2008).

Spirulina platensis, a blue green algae rich in proteins, essential amino acids, antioxidants like Vitamin $C, \beta$ carotenes and tocopherols (Abd El-Baky et al., 2003; Ciferri and Tiboni, 1985; Khan et al., 2005) inhibits the lipid peroxidation more significantly than chemical antioxidants (Manoj et al., 1992).

The present study was conducted to study the effect of dietary inclusion of neem leaf powder, alone and in combination with spirulina, on maintaining quality of broiler chicken meat and their effect on meat sensory parameters.

\section{Materials and Methods}

\section{Experimental design and management}

A total of 90 , day-old Vencobb broiler chicks (M/s Srinivasa Hatcheries, Vijayawda) were randomly distributed to 6 groups of 15 birds and were maintained in battery cages. Birds were maintained with 24 hours of light in the first week, followed by 20 hours lighting from the second week through the end of the experimental study. The ambient temperature ranged between $32-35{ }^{\circ} \mathrm{C}$ with a relative humidity of $65 \%$. All the birds were kept under uniform managemental conditions with ad libitum feed and water. Standard vaccination and management practices were followed throughout the experiment. Neem leaves collected locally were shade dried and grounded to powder with willey mill. Spirulina platensis powder (M/s Parry Neutraceuticals, Chennai) and oxytetracycline were obtained from commercial sources.

The feed given to different groups consisted of normal feed (Group I), feed containing oxytetracycline-200 (TM$200^{*}$ ) at the concentration of $0.05 \%$ (Group II), feed containing NLP of $0.2 \%$ (Group III), feed containing NLP of $0.2 \%$ and spirulina of $1 \%$ (Group IV), feed containing TM-200 of $0.05 \%$ and spirulina of $1 \%$ (Group V) and feed containing spirulina of $1 \%$ (Group VI).

At the end of 42 days all the birds were sacrificed by decapitation. Liver, kidney and muscle samples were collected to evaluate the tissue peroxidation markers viz. TBARS (Balasubramanian et al., 1988) and protein carbonyls (Levine et al., 1990) and antioxidant marker SOD (Madesh and Balasubramanian, 1998).

Physico-chemical quality determinants of both fresh and preserved meat viz. extract release volume (ERV) (Jay and Kalliopi, 1964), water holding capacity (WHC) (Whiting and Jenkins, 1981) and $\mathrm{pH}$ (Trout et al., 1992) using digital $\mathrm{pH}$ meter were also studied.

Organoleptic evaluation of oil cooked meat as judged by color, flavor, juiciness, tenderness and overall acceptability was done as per 9 point Hedonic scale that ranged from 1-dislike extremely to 9-extremely like with semi trained taste panel regarding to the aspects of color, flavor, juiciness, tenderness and overall acceptability.

\begin{tabular}{cl}
\hline Score & \multicolumn{1}{c}{ Interpretation } \\
\hline 9 & Excellent (like extremely) \\
8 & Good (like very much) \\
7 & Moderately good (like moderately) \\
6 & Just good (like slightly) \\
5 & Fair (neither like nor dislike) \\
4 & Just poor (dislike slightly) \\
3 & Moderately poor (dislike moderately) \\
2 & Poor (dislike very much) \\
1 & Extremely poor (dislike extremely) \\
\hline
\end{tabular}

Statistical analysis

The data was subjected to statistical analysis by applying one way ANOVA using statistical package for social sciences (SPSS) version 17. Differences between the means were tested using Duncan's multiple comparision test and significance was set at $\mathrm{P}<0.05$.

\section{Results}

\section{Peroxidation and antioxidant markers}

By the end of the seventh week of experimental period, the levels of TBARS were found significantly decreased in all groups compared to the control group. Maximum decrease in TBARS was observed in group V followed by group II as indicated in Table 1. Protein carbonyls indicated a significant $(\mathrm{P}<0.05)$ decrease in all the treated groups compared to control. In kidney the decrease was highly significant $(\mathrm{P}<0.05)$ in group II and V while in muscle tissue, maximum decrease was noticed in group II, IV and V (Table 1). Superoxide dismutase levels were found to be significantly increased in all the treated groups in all the tissues collected (Table 1).

\section{Physico-chemical quality parameters of the meat}

The extract release volume and water holding capacity values were found to be significantly increased in all the treated groups both in fresh as well as in preserved meat. In contrast, the $\mathrm{pH}$ values were found significantly lowered in fresh meat and in preserved meat in all the treated groups (Table 2).

\section{Organoleptic characteristics}

Organoleptic characteristics like tenderness, juciness, flavor, color and overall acceptability were found unaltered with respect to fresh meat in all the treated groups compared to control (Table 3).

\section{Discussion}

In all the treated groups, a significant decrease in tissue peroxidation markers (TBARS and protein carbonyls) and a significant increase in tissue antioxidant marker (SOD) were observed in liver, kidney and muscle. Overall comparison of the antioxidant status profiles in various treated groups revealed their highest levels in antibiotic plus spirulina group followed by antibiotic group, neem plus spirulina group, neem group and spirulina group in descending order. This revealed that the treated birds had higher stress tolerance levels or otherwise lowered physiological stress compared to control birds. This can be attributed to different mechanisms of action of treatments.

Generally oxidative damage occurs in in vivo conditions due to altered equilibrium between the production of reactive oxygen or nitrogen species and the constituent defense mechanisms. It is generally accepted that lipid oxidation is one of the primary mechanism of quality deterioration in meat (Morrissey et al., 1998). The extent of lipid oxidation in meat can be measured by 
402

estimating the thiobarbituric acid reactive substance concentration (Raharjo and Sofos, 1993).

As a major component of muscle tissue, proteins play a decisive role in meat and meat products (Lawrie, 1998). Muscle protein oxidation produces deleterious effects on meat quality (Decker et al., 1993; Mercier et al., 1995). Protein oxidation is known to affect meat quality including texture (Kemp et al., 2010), color (Kazemi et al., 2011), flavor (Toldra, 1998) and WHC (Van Laack et al., 2000).

Subapriya et al. (2005), Sithisaran et al. (2005), Ghimeray et al. (2009) and Kiranmai et al. (2011) reported the antioxidant potential of various parts of neem in both in vivo and in vitro experimental studies. Subapriya et al. (2005) stated that ethanolic extract of neem contains a number of antioxidants including terpinoids, limonoids, quercetin and sitosterols.

The results observed according to spirulina in respect to increasing antioxidant status in the present study are akin to the earlier reports that come from in vitro, animal and human studies (Miranda et al., 1998 and Won-Loy Chu et al., 2010). Hayashi et al. (2009) stated that phycocyanobilin a phytochemical richly present in spirulina, reportedly inhibits NADPH oxidase activity and promotes glutathione synthesis along with a marked production of antioxidant enzyme having potential for management of oxidative stress.

It is known that many active components in herbs slow down the lipid peroxidation by activation of enzymes like SOD, catalase and glutathione peroxidase (Botsoglou et al., 2003). Herbs containing polyphenolic substances, that possess antioxidant properties, can improve the shelf-lifeand quality of meat and meat products (Liu et al., 1992; Botsoglou et al., 2002). Lipid and hydroxyl radicals were neutralized by herbal phenolic components (Yanishlieva-Maslarova, 2001). A significant antioxidant activity in lamb meat was observed during a dietary treatment with oregano essential oil which is rich in phenols (Simitzis et al., 2008). Several researchers have reported the possibility of antioxidative effects for some traditional herbs (Park and Yoo, 1999; Liu et al., 2006). Decker (2000) opined that oxidative stability of meat can be improved by managing animal feeds.

Dietary supplementation with garlic bulb also resulted in significantly lower TBARS value in chicken thigh muscle compared with muscle from birds fed non supplemented diets (Kim et al., 2009). In a similar study, Jang et al. (2008) observed increased antioxidant activity in the breast meat as evidenced by decreased TBARS compared to control birds in broiler chicks fed with dietary medicinal herb extract mix. Increased antioxidant activity results in increased protection against the stresses caused by lipid oxidation. The decreased TBARS and protein carbonyls and increased SOD activity implies that the shelf-life of the meat can be improved by dietary supplementation of neem, spirulina and their combination.

Good quality meat with a relatively low bacterial count releases large volumes of extract (ERV) (Jay and Kalliopi, 1964) and will have higher water holding capacity (WHC) (Jay, 1965). A lower WHC in muscle can induce liquid outflow, loss of soluble nutrients and flavor and thereby reducing the meat quality since the muscle become hard and tasteless (Barbut, 1996). In the present study it was observed that WHC and ERV at the time of slaughter were significantly higher in all the treated groups compared to the control. Similar trend was observed even after one-week storage.

The ultimate $\mathrm{pH}$ of meat is highly dependent on the amount of glycogen present in the muscle. This glycogen is

Table 1. Antioxidant profile of different tissues from birds fed with neem leaf and/or spirulina substituted diet

\begin{tabular}{|c|c|c|c|c|c|c|c|c|c|}
\hline \multirow[t]{2}{*}{ Group } & \multicolumn{3}{|c|}{ TBARS ( $\mu \mathrm{M}$ of MDA/mg of protein) } & \multicolumn{3}{|c|}{ Protein carbonyls(nM/100mg protein) } & \multicolumn{3}{|c|}{$\mathrm{SOD}(\mathrm{U} / \mathrm{mg}$ of protein) } \\
\hline & Liver & Kidney & Muscle & Liver & Kidney & Muscle & Liver & Kidney & Muscle \\
\hline I & $4.50 \pm 0.14^{\mathrm{C}}$ & $3.27 \pm 0.17^{\mathrm{C}}$ & $2.49 \pm 0.07^{\mathrm{C}}$ & $22.45 \pm 0.55^{\mathrm{B}}$ & $13.51 \pm 1.30^{\mathrm{C}}$ & $6.04 \pm 0.35^{\mathrm{C}}$ & $9.84 \pm 0.29^{A}$ & $7.34 \pm 0.35^{\mathrm{A}}$ & $6.49 \pm 0.21^{\mathrm{A}}$ \\
\hline II & $2.79 \pm 0.17^{\mathrm{A}}$ & $2.01 \pm 0.31^{\mathrm{A}}$ & $1.37 \pm 0.21^{A}$ & $19.34 \pm 0.95^{\mathrm{A}}$ & $10.65 \pm 0.95^{\mathrm{A}}$ & $4.69 \pm 0.51^{\mathrm{A}}$ & $12.75 \pm 0.48^{\mathrm{C}}$ & $8.87 \pm 0.41^{\mathrm{B}}$ & $7.85 \pm 0.31^{\mathrm{B}}$ \\
\hline III & $3.34 \pm 0.08^{\mathrm{B}}$ & $2.65 \pm 0.27^{\mathrm{B}}$ & $1.85 \pm 0.13^{\mathrm{B}}$ & $20.27 \pm 0.89^{\mathrm{A}}$ & $11.43 \pm 1.01^{\mathrm{B}}$ & $5.01 \pm 0.41^{\mathrm{B}}$ & $11.76 \pm 0.25^{\mathrm{B}}$ & $8.12 \pm 0.39^{\mathrm{B}}$ & $7.21 \pm 0.28^{\mathrm{B}}$ \\
\hline IV & $3.09 \pm 0.16^{\mathrm{B}}$ & $2.35 \pm 0.14^{\mathrm{B}}$ & $1.78 \pm 0.17^{\mathrm{B}}$ & $19.89 \pm 1.21^{\mathrm{A}}$ & $11.09 \pm 1.20^{\mathrm{B}}$ & $4.85 \pm 0.35^{\mathrm{A}}$ & $12.01 \pm 0.37^{\mathrm{C}}$ & $8.35 \pm 0.35^{\mathrm{B}}$ & $7.45 \pm 0.22^{\mathrm{B}}$ \\
\hline V & $2.38 \pm 0.13^{\mathrm{A}}$ & $1.90 \pm 0.12^{\mathrm{A}}$ & $1.25 \pm 0.09^{\mathrm{A}}$ & $18.79 \pm 1.02^{\mathrm{A}}$ & $10.13 \pm 0.75^{\mathrm{A}}$ & $4.36 \pm 0.47^{\mathrm{A}}$ & $13.36 \pm 0.57^{\mathrm{D}}$ & $9.02 \pm 0.47^{\mathrm{C}}$ & $8.03 \pm 0.26^{C}$ \\
\hline VI & $3.76 \pm 0.21^{\mathrm{B}}$ & $2.75 \pm 0.15^{\mathrm{B}}$ & $1.96 \pm 0.11^{\mathrm{B}}$ & $20.84 \pm 1.09^{\mathrm{A}}$ & $11.87 \pm 0.45^{\mathrm{B}}$ & $5.43 \pm 0.27^{\mathrm{B}}$ & $11.14 \pm 0.39^{\mathrm{B}}$ & $7.98 \pm 0.27^{\mathrm{A}}$ & $7.11 \pm 0.36^{\mathrm{B}}$ \\
\hline
\end{tabular}

Table 2. Physico-chemical profiles of tissues of fresh and preserved broiler chicken meat fed with neem leaf and/or spirulina substituted diet

\begin{tabular}{|c|c|c|c|c|c|c|}
\hline \multirow[t]{2}{*}{ Group } & \multicolumn{2}{|c|}{$\mathrm{ERV}(\mathrm{ml})$} & \multicolumn{2}{|c|}{ WHC (\%) } & \multicolumn{2}{|c|}{$\mathrm{pH}$} \\
\hline & Fresh & $1^{\text {st }}$ week & Fresh & $1^{\text {st }}$ week & Fresh & $1^{\text {st }}$ week \\
\hline I & $22.00 \pm 0.61^{\mathrm{A}}$ & $21.00 \pm 0.60^{\mathrm{A}}$ & $59.39 \pm 0.31^{\mathrm{A}}$ & $57.49 \pm 0.66^{\mathrm{A}}$ & $5.69 \pm 0.04^{\mathrm{D}}$ & $5.72 \pm 0.03^{\mathrm{D}}$ \\
\hline II & $26.00 \pm 0.58^{\mathrm{BC}}$ & $25.00 \pm 0.56^{\mathrm{CD}}$ & $63.98 \pm 0.47^{\mathrm{CD}}$ & $62.68 \pm 0.34^{\mathrm{D}}$ & $5.51 \pm 0.02^{\mathrm{AB}}$ & $5.55 \pm 0.02^{\mathrm{B}}$ \\
\hline III & $24.00 \pm 0.66^{\mathrm{B}}$ & $23.00 \pm 0.60^{\mathrm{B}}$ & $61.85 \pm 0.65^{\mathrm{B}}$ & $60.81 \pm 0.46^{\mathrm{B}}$ & $5.60 \pm 0.03^{C}$ & $5.63 \pm 0.02^{C}$ \\
\hline IV & $25.50 \pm 0.70^{\mathrm{BC}}$ & $24.50 \pm 0.60^{C}$ & $62.70 \pm 0.53^{C}$ & $61.40 \pm 0.32^{\mathrm{C}}$ & $5.53 \pm 0.01^{\mathrm{BC}}$ & $5.58 \pm 0.01^{B}$ \\
\hline V & $27.50 \pm 0.86^{\mathrm{C}}$ & $26.00 \pm 0.47^{\mathrm{D}}$ & $64.68 \pm 0.37^{\mathrm{D}}$ & $63.49 \pm 0.31^{\mathrm{E}}$ & $5.47 \pm 0.02^{\mathrm{A}}$ & $5.51 \pm 0.01^{\mathrm{A}}$ \\
\hline VI & $23.50 \pm 0.62^{\mathrm{B}}$ & $22.50 \pm 0.60^{\mathrm{B}}$ & $61.40 \pm 0.40^{\mathrm{B}}$ & $60.10 \pm 0.36^{\mathrm{B}}$ & $5.62 \pm 0.02^{C}$ & $5.65 \pm 0.02^{C}$ \\
\hline
\end{tabular}

Note: Values are Mean \pm S.E ( $\mathrm{n}=15)$ one way ANOVA (SPSS). Means with different superscripts differ significantly $(\mathrm{P}<0.05)$

Table 3. Organoleptic characteristics of fresh meat in different groups of broiler chicks fed with neem leaf and/or spirulina substituted diet

\begin{tabular}{|c|c|c|c|c|c|}
\hline Group & Tenderness & Juiciness & Flavor & Color & Overall acceptability \\
\hline I & $7.14 \pm 0.27$ & $6.84 \pm 0.26$ & $6.83 \pm 0.31$ & $7.29 \pm 0.36$ & $6.85 \pm 0.26$ \\
\hline II & $7.24 \pm 0.26$ & $7.14 \pm 0.26$ & $7.00 \pm 0.26$ & $7.57 \pm 0.20$ & $7.14 \pm 0.26$ \\
\hline III & $8.29 \pm 0.29$ & $7.86 \pm 0.40$ & $7.83 \pm 0.31$ & $7.29 \pm 0.29$ & $8.00 \pm 0.39$ \\
\hline IV & $7.43 \pm 0.37$ & $7.57 \pm 0.30$ & $7.67 \pm 0.33$ & $7.57 \pm 0.37$ & $7.57 \pm 0.20$ \\
\hline V & $7.14 \pm 0.26$ & $7.14 \pm 0.34$ & $7.50 \pm 0.43$ & $7.57 \pm 0.37$ & $7.43 \pm 0.37$ \\
\hline VI & $8.00 \pm 0.31$ & $7.17 \pm 0.27$ & $7.33 \pm 0.21$ & $7.57 \pm 0.20$ & $7.43 \pm 0.20$ \\
\hline
\end{tabular}


depleted in the muscles of birds that have been exposed to stress (Ngoka and Froning, 1982). Since $\mathrm{pH}$ is an important determinant of microbial growth, it is obvious that ultimate $\mathrm{pH}$ of meat is significant for its resistance to spoilage. Post mortem $\mathrm{pH}$ of the meat is determined by the amount of lactic acid produced from glycogen during anaerobic glycolysis and this will be curtailed if glycogen is depleted by fatigue, inanition or fear in the animal before slaughter (Lawrie, 1998). $\mathrm{pH}$ of the meat at slaughter and after storage in treated groups remained significantly lower compared to control. This indicated better muscle glycogen reserves in all treated groups which indirectly reflect reduced stress on birds.

Thus, favorable WHC, ERV and $\mathrm{pH}$ values of the meat from neem and spirulina treated birds suggest that both the agents enhance the shelf-life and quality of the meat. This is in accordance with the results of the study made by Chen $e t a l$. (2008) where the pork from pigs fed with garlic powder showed increased WHC with no effect on color, marbling and firmness. WHC also increased in pork of pigs fed on $2 \mathrm{~g}$ of fresh spirulina with forage (Almantas et al., 2013). Young et al. (2003) attributed the increase in WHC of broiler breast muscle in favour of the improvement of the antioxidant activity via inhibition of TBARS.

To know the general consumer acceptance of the meat from the treated birds, meat sensory attributes in terms of color, flavor, tenderness, juiciness and overall acceptability on fresh basis were studied using sensory panel. It was observed that none of the sensory attributes were adversely affected indicating no negative impact on the general acceptance of the meat from neem and spirulina fed birds. The inclusion of neem at rates up to $2 \%$ in feed did not alter the aroma, color, flavor, texture, juiciness and overall acceptability of broiler meat as stated by Bonsu et al. (2012). Egbeyale et al. (2014) reported that inclusion of neem leaf meal at the rate of $0.5 \%$ in broiler diets produced better results in terms of growth without effecting carcass charecterstics. Also there was no modification in organoleptic properties of chicken meat fed on diets containing spirulina at $1 \%, 2.5 \%$ and $5 \%$ level as reported by Raach-Moujahed et al. (2011).

\section{Conclusions}

Enhanced stress tolerance levels and improved meat quality with unaffected consumer acceptance levels of the meat observed in the study, with neem and spirulina either alone or in combinations, indicated that neem at $0.2 \%$ level can be used in poultry diets instead of AGPs. However, much favorable results were obtained in the present study when neem was used in combination with spirulina than when it was used alone.

\section{Acknowledgements}

The funds and facilities provided by NTR College of Veterinary Science and Sri Venkateswara Veterinary University, Tirupati for the postgraduate grant and facilities are thankfully acknowledged.

\section{References}

Abd El-Baky HH (2003). Over production of phycocyanin pigment in blue green Alga Spirulina sp. and it's inhibitory effect on growth of Ehrlich ascites carcinoma cells. Journal of Medical Sciences $3(4): 314-324$.
Hashemi SR, Idrus Z, Bejo MH, Abas F, Somchit MN (2008). Acute toxicity study and phytochemical screening of selected herbal aqueous extract in broiler chickens. International Journal of Pharmacology 4(5):352-360.

Hayashi O, Katayanagi Y, Ishii K, Kato T (2009). Flow cytometric analysis of age-related changes in intestine intraepithelial lymphocyte subsets and their functional preservation after feeding mice on Spirulina. Journal of Medicinal Food 12(5):982-989.

Hernandez F, Madrid J, Garcia V, Orengo J, Megias MD (2004). Influence of two plant extracts on broiler performance, digestability and digestive organ size. Poultry Science 83(2):169-174.

Jang A, Liu XD, Shin MH, Lee BD, Lee SK, Lee JH, Jo C (2008). Antioxidative potential of raw breast meat from broiler chicks fed a dietary medicinal herb extract mix. Poultry Science 87(11):2382-2389.

Jay JM (1965). Relationship between water-holding capacity of meats and microbial quality. Applied Microbialogy 13(1):120-121.

Jay JM, Kontou KS (1964). Evaluation of the extract-release volume phenomena as a rapid test for detecting spoilage of beef. Applied Microbiology 12(4):378-383.

Kamel C (2000). A novel look at a classical approach of plant extracts. Feed Mix (special issue on Nutraceuticals) $8(3): 16-18$.

Kanner J (1994). Oxidative processes in meat and meat products: quality implications. Meat Science 36(1):169189.

Kazemi S, Ngadi MO, Gariepy C (2011). Protein denaturation in pork longissimus muscle of different quality groups. Food and Bioprocess Technology $4(1): 102-106$.

Kemp CM, Sensky PL, Bardsley RG, Buttery PJ, Parr T (2010). Tenderness-an enzymatic view. Meat Science 84(2):248-256.

Khan Z, Bhadouria P, Bisen PS (2005). Nutritional and therapeutic potential of Spirulina. Current Pharmaceutical Biotechnology 6(5):373-379.

Kim YJ, Jin SK, Yang HS (2009). Effect of dietary garlic bulb and husk on the physicochemical properties of chicken meat. Poultry Science 88(2):398-405.

Kiranmai M, Mahender Kumar CB, Ibrahim MD (2011). Free radical scavenging activity of neem tree (Azadirachta indica A. juss var. Meliaceae) root bark extract. Asian Journal of Pharmaceutical and Clinical Research $4(4): 134-136$.

Klasing KC (1998). Comparative avian nutrition. Cambridge University Press, London.

Koul O, Isman MB, Ketkar CM (1990). Properties and uses of neem, Azadirachta indica. Canadian Journal of Botany 68(1):1-11.

Lawrie RA (1998). The conversion of muscle to meat. In: Lawrie's Meat Science, 6th ed Woodhead Publishing Ltd, Cambridge, England pp 96-118. 
404

Levine RL, Garland D, Oliver CN, Amici A, Climent I, Lenz AG, Ahn BW, Shaltiel S, Stadtman ER (1990). Determination of carbonyl content in oxidatively modified proteins. Methods in Enzymology 186:464-478.

Liu B, Li W, Chang Y, Dong W, Ni L (2006). Extraction of berberine from rhizome of Coptis chinensis franch using supercritical fluid extraction. Journal of Pharmaceutical and Biomedical Analysis 41(3):1056-1060.

Liu HF, Booren AM, Gray JI, Crackel RL (1992). Antioxidant efficacy of oleoresin rosemary and sodium tripolyphosphate in restructured pork steaks. Journal of Food Science 57(4):803-806.

Madesh M, Balasubramanian KA (1998). Microtitre plate assay for superoxide dismutase using MTT reduction by superoxide. Indian Journal of Biochemistry and Biophysics 35(3):184-188.

Manoj G, Venkataraman LV, Srinivas L (1992). Antioxidant properties of spirulina (Spirulina platensis). In: Seshadri $\mathrm{CV}$, Bai NJ (Eds). Spirulina: National Symposium (India), MCRC, Tharamani, Madras 48:154-158.

McCartney E (2002). Features-the natural empire strikes back "Natural" growth promoters show potential. Poultry International 41(1):36-42.

Mercier Y, Gatellier P, Renerre M (1995). Relationships between lipid and protein oxidation in different beef muscles. In: Proceedings of the $41^{\text {st }}$ international congress of meat science and technology. San Antonio USA pp 562-564.

Miranda MS, Cintra RG, Barros SBM, Mancini-Filho J (1998). Antioxidant activity of the microalga Spirulina maxima. Brazilian Journal of Medical and Biological Research 31(8):1075-1079.

Morrissey PA, Sheehy PJA, Galvin K, Kerry JP, Buckley DJ (1998). Lipid stability in meat and meat products. Meat Science 49:73-86.

Ngoka DA, Froning GW (1982). Effect of free struggle and preslaughter excitement on color of turkey breast muscle. Poultry Science 61(11):2291-2293.

Park SJ, Yoo SO (1999). Effects of supplementation of Chinese medicine refuse on performance and physiology in broiler chicks. Korean Journal of Poultry Science 26(3):195-201.

Raach-Moujahed A, Hassani S, Zairi S, Bouallegue M, Darej C, Haddad B, Damergi C (2011). Effect of dehydrated Spirulina platensis on performance and meat quality of broilers. Research Opinions in Animal and Veterinary Sciences 1(8):505-509.

Raharjo S, Sofos JN (1993). Methodology for measuring malonaldehyde as a product of lipid peroxidation in muscle tissues: A review. Meat Science 35(2):145-169.
Sahin K, Sahin N, Onderci M, Yaralioglu S, Kucuk O (2001). Protective role of supplemental vitamin $\mathrm{E}$ on lipid peroxidation, vitamins $\mathrm{E}, \mathrm{A}$ and some mineral concentrations of broilers reared under heat stress. Veterinarni Medicina Praha 46(5):140-144.

Simitzis PE, Deligeorgis SG, Bizelis JA, Dardamani A, Theodosiou I, Fegeros K (2008). Effect of dietary oregano oil supplementation on lamb meat characteristics. Meat Science 79(2):217-223.

Šimkus A, Šimkienė A, Černauskiené J, Kvietkutė N, Černauskas A, Paleckaitis M, Kerzienè S (2013). The effect of blue algae Spirulina platensis on pig growth performance and carcass and meat quality. Veterinarija Ir Zootechnika 61(83):70-74.

Sithisarn P, Supabphol R, Gritsanapan W (2005). Antioxidant activity of Siamese neem tree. Journal of Ethanopharmacology 99(1):109-112.

Subapriya R, Nagini S (2005). Medicinal properties of neem leaves: a review. Current Medicinal Chemistry -AntiCancer Agents 5(2):149-156.

Subapriya R, Bhuvaneswari V, Nagini S (2005). Ethanolic neem (Azadirachta indica) leaf extract induces apoptosis in the hamster buccal pouch carcinogenesis model by modulation of Bcl-2, Bim, Caspase 8 and Caspase 3 . Asian Pacific Journal of Cancer Prevention 6(4):515-520.

Tipu MA, Akhtar MS, Anjum MI, Raja ML (2006). New dimension of medicinal plants as animal feed. Pakistan Veterinary Journal 26(3):144-148.

Toldra F (1998). Proteolysis and lipolysis in flavor development of dry-cured meat products. Meat Science 49:101-110.

Troutt ES, Hunt MC, Johnson DE, Claus JR, Kashner CL, Krolpf DH, Stroda S (1992). Chemical, physical and sensory characteristics of ground beef containing 5 to 30 percent fat. Journal of Food Science 57(1):25-29.

Van Laack RLJM, Liu CH, Smith MO, Loveday HD (2000). Characteristics of pale, soft, exudative broiler breast meat. Poultry Science 79(7):1057-1061.

Whiting RC, Jenkins RK (1981). Comparison of rabbit, beef and chicken meats for functional properties and frankfurter processing. Journal of Food Science 46(6):1693-1696.

Yanishlieva-Maslarova NV (2001). Inhibiting oxidation. In: Pokorny J, Yanishlieva N, Gordon M (Eds). Antioxidants in food: practical applications. Woodhead Publishing Limited, CRC Press, Cambridge, England pp 22-70.

Young JF, Stagsted J, Jensen SK, Karlsson AH, Henckel P (2003). Ascorbic acid, alpha-tocopherol and oregano supplements reduce stress-induced deterioration of chicken meat quality. Poultry Science 82(8):1343-1351. 